\title{
Optimal Management of Partial Thickness Rotator Cuff Tears: Clinical Considerations and Practical Management
}

\author{
Tanujan Thangarajah (D), lan K Lo \\ Department of Trauma and Orthopaedic Surgery, University of Calgary, Calgary, Alberta, Canada \\ Correspondence: Tanujan Thangarajah, Department of Trauma and Orthopaedic Surgery, University of Calgary, Calgary, Alberta, Canada, \\ Email tanujanI@hotmail.com
}

\begin{abstract}
Partial thickness rotator cuff tears have been diagnosed with increased frequency due to heightened awareness and an improvement in diagnostic modalities. When $>50 \%$ of the tendon thickness has ruptured, intra-tendinous strain of the residual tendon increases. Surgery is generally confined to patients who have failed non-operative measures and have persistent symptoms. The rationale for repairing partial thickness tears lies in their limited self-healing capacity, and propensity to enlarge over time and progress to a full thickness defect. Although tear debridement and acromioplasty can improve pain and function, tear progression can occur, in addition to worse results being noted in bursal-sided defects. Several surgical strategies have been recommended but there is a lack of evidence to advocate one form of treatment over another. The aim of this narrative review is to discuss the treatment options for partial thickness tears of the rotator cuff.
\end{abstract}

Keywords: arthroscopy, rotator cuff, shoulder pain, tendon injuries

\section{Introduction}

Partial thickness rotator cuff tears (PTRCTs) have been diagnosed with increased frequency due to heightened awareness and an improvement in diagnostic modalities. ${ }^{1}$ The overall prevalence of rotator cuff abnormalities increases with age, from $9.7 \%$ in those 20 years and younger, to $62 \%$ in those aged 80 years and older. ${ }^{2}$ Similarly, PTRCTs are more likely to occur in older individuals and have an estimated prevalence of between $13 \%$ and $32 \% .^{3-6}$ The true scale of the problem may be greater than originally reported due to the difficulties in identifying intra-tendinous lesions, which account for over half of partial thickness defects. ${ }^{7}$

Non-operative management can improve clinical outcomes but do not address the underlying tear. ${ }^{8}$ Over $40 \%$ of asymptomatic partial thickness defects progress to full thickness tears within three years. ${ }^{9}$ In those who fail to respond to non-operative measures, surgery may offer a solution. Current operative strategies are governed by the thickness of the tendon affected, with greater than $50 \%$ involvement traditionally considered as the point at which a repair should be considered. ${ }^{10}$ This is primarily due to the significant increase in intra-tendinous strain observed beyond this, and its influence on tear propagation. ${ }^{1,10}$

Of the surgical options described in the literature, the simplest entails a subacromial decompression (acromioplasty and bursectomy) and tear debridement. On the opposite end of the spectrum, the most aggressive strategy involves converting the defect to a full thickness tear and repairing it. The principal limitation of this approach is that excising the native tendon can permanently alter the footprint and disrupt the normal length-tension relationship of the musculotendinous unit. ${ }^{11}$ Trans-tendinous repair offers an intermediate solution and has gained in popularity but has not shown superiority to a conversion to full thickness tear and repair, and increases the risk of pain and stiffness. ${ }^{12}$ More recently, there has been a growing interest in the use of innovative biological solutions such as highly porous bioinductive bovine 
collagen implants. Although early results of this resorbable graft are encouraging, with an improvement in clinical outcome and increased mean tendon thickness, no long-term comparative studies have been conducted. ${ }^{13}$

The purpose of this narrative review is to discuss the treatment options for partial thickness tears of PTRCTs.

\section{Aetiology and Pathogenesis}

PTRCTs are likely to occur as the end result of a common pathway that is mediated by both intrinsic and extrinsic factors. ${ }^{14}$ Intrinsic factors comprise age-related microscopic changes (hypocellularity, fascicular thinning, dystrophic calcification, and accumulation of granulation tissue), hypovascularity, and alterations in intra-tendinous strain., ${ }^{4,5}, 15-17$ Extrinsic factors encompass structural causes such as subacromial impingement, micro-instability, and internal impingement (contact between the postero-superior aspect of the glenoid and the under-surface of the rotator cuff). ${ }^{18-20}$ Other causative factors include Trauma, metabolic factors (diabetes, hypolipidaemia, and metabolic syndrome), and a genetic predisposition. ${ }^{7,21,22}$ The articular part of the rotator cuff is particularly vulnerable to tearing because of its proximity to the zone of hypovascularity located lateral to the rotator cable. Its less organised collagen structure has an ultimate stress to failure half that of the bursal surface. ${ }^{23}$

Clark and Harryman demonstrated that the rotator cuff insertion consisted of five distinct histological layers. ${ }^{24}$ The first layer is the superficial coracohumeral ligament. The second and third layers contain the tendinous fibres of the rotator cuff, and the remaining fourth and fifth layers comprise loose connective tissue and the shoulder joint capsule. This arrangement predisposes to the development of internal shear forces between the layers that leads to a rise in intratendinous strain and further tissue degeneration, impaired healing and tear propagation. ${ }^{16,25-28}$ Intra-tendinous strain can additionally be elevated during shoulder abduction and can potentially result in an articular-sided tear. ${ }^{16,25}$ This mechanism has been cited in the development of PTRCTs in overhead-throwing athletes, whose rotator cuff tendons are subjected to repetitive and powerful eccentric forces. ${ }^{1}$

Yamanaka and Matsumoto ${ }^{29}$ reported that after one year, $28 \%$ of PTRCTs progressed to full thickness defects and $80 \%$ increased in size. This though may represent an overestimation, with more recent reports suggesting that at four years, no significant progression occurs in $76 \%$ of cases and only $8 \%$ of patients develop a full thickness tear. ${ }^{8}$ In a longer-term follow-up study by Ranebo et al, ${ }^{30} 43$ patients with PTRCTs were reviewed at a minimum of 20 years after an acromioplasty without repair. The majority of tears did not propagate (42\%) and cuff tear arthropathy rarely occurred ( $7 \%$ of cases). Tear progression is associated with the percentage of the tendon thickness involved. In patients with tears involving over $50 \%$ of the tendon thickness, $55 \%$ exhibited progression compared to those with less than $50 \%$ of the thickness involved who had tear progression in $14 \%$ of cases. ${ }^{8}$ While some clinical studies suggest that PTRCTs do not spontaneously heal, basic science studies have demonstrated an active cellular response in these defects that implies some self-healing properties. ${ }^{31-33}$

\section{Classification}

PTRCTs are defined according to their location (articular, bursal, and intra-tendinous), tendons involved, and the percentage of the tendon thickness affected. ${ }^{1}$ The widely used Ellman classification incorporates location, depth (grade 1, $<3 \mathrm{~mm}$ deep; grade 2, 3-6 $\mathrm{mm}$ deep; grade 3, $>6 \mathrm{~mm}$ deep), and area $\left(\mathrm{mm}^{2}\right)$ to define the tear. Despite the popularity of this system, inter-observer reliability is poor and it fails to consider tissue quality and aetiology (acute vs chronic vs acute-on-chronic). ${ }^{7,34-36}$

In overhead athletes, articular-sided injuries most often involve the posterior supraspinatus and anterior infraspinatus. ${ }^{37}$ This is thought to arise due to internal impingement and/or anatomical deficiencies in the articular portion of the rotator cuff such as hypovascularity and disorganised collagen arrangement. ${ }^{5,24,38}$ Millstein and Snyder coined the PASTA lesion to describe a partial articular supraspinatus tendon avulsion, following which it was recognised as a distinct pathological entity. ${ }^{39}$ Conway expanded on this variant by describing a partial articular tear with intratendinous extension (PAINT lesion) and an intact footprint. ${ }^{40}$ Bursal-sided tears can be associated with subacromial impingement due to a bony spur, and are thus considered more of a degenerative lesion. ${ }^{18}$ However, evidence for this is limited particularly since an acromial spur is in fact a traction enthesophyte within the coracoacromial ligament that occurs as the humeral head passes below it, thus placing the ligament under increased tension. ${ }^{41}$ 


\section{Non-Operative Treatment}

Non-operative treatment is a viable first-line option for partial thickness tears owing to their low risk of tear progression, fatty infiltration, and muscle atrophy. ${ }^{29}$ Physiotherapy, anti-inflammatory medication, and activity modification are the first-line approach. A formal exercise regime should focus on scapulo-humeral dynamics, postural control, and posterior capsular stretching. Corticosteroid injections offer an appealing solution to residual pain but increase the risk of complications and revision surgery following rotator cuff repair. ${ }^{42}$ Lo et al ${ }^{8}$ followed-up 37 patients who underwent nonoperative treatment for a PTRCT. After a mean follow-up of $46 \pm 7$ months there was an improvement in functional outcome, with $76 \%$ of tears not exhibiting a progression in size.

\section{Indications for Surgery}

The rationale for repairing partial thickness tears lies in their limited self-healing capacity, and propensity to enlarge over time and progress to a full thickness defect. ${ }^{29,32,33,43,44}$ Surgery is generally confined to those who have failed nonoperative measures and have persistent pain and/or disability. A number of operative strategies have been described but the choice has traditionally been based upon whether the patient will benefit from a formal repair or a less invasive procedure such as a debridement \pm acromioplasty.

Several factors influence the decision to operate (eg patient age, activity level, concomitant pathology, occupation) but it is the percentage of tendon thickness involved that is often regarded as the most important consideration. ${ }^{1,7}$ The rationale for this emanates from the retrospective study carried out by Weber et $\mathrm{al}^{45}$ in which patients with tearing of $>50 \%$ of their tendon thickness demonstrated superior clinical outcomes [improvement in the University of California, Los Angeles Shoulder (UCLA) Rating Scale and lower reoperation rate] with mini-open repair compared to arthroscopic acromioplasty alone. This has subsequently been supported by a number of biomechanical studies that have shown an increase in intra-tendinous strain of the residual tendon substance when $>50 \%$ of the thickness has been ruptured. ${ }^{10,28}$

\section{Arthroscopic Procedures}

An arthroscopic-based operation has the distinct advantage over open surgery in that it affords a comprehensive evaluation of the intra-articular and subacromial spaces. There is currently insufficient evidence to advocate one specific procedure for the treatment of high-grade partial thickness tears, however irrespective of the technique employed, an improvement in functional outcome can reliably be achieved. ${ }^{46}$ Current surgical strategies include tear debridement with or without acromioplasty, conversion to full-thickness defect and repair, in situ repair, and biological augmentation strategies.

\section{Tear Debridement with or without Acromioplasty}

Tears that affect $<50 \%$ of the tendon thickness can be managed successfully with a debridement \pm acromioplasty (Table 1). ${ }^{30,47-52}$ Budoff et $\mathrm{al}^{48}$ reviewed 60 patients who had undergone an isolated rotator cuff debridement without an acromioplasty for a PTRCT. Using the UCLA Rating Scale there were 79\% excellent or good results at an average of 114 months follow-up, and $77 \%$ had no or very little pain.

Favourable results have not been reported ubiquitously though. Kartus et $\mathrm{al}^{51}$ followed-up 26 patients who underwent an acromioplasty in conjunction with a tear debridement. At 101 months, 35\% of partial thickness tears had progressed to full thickness defects. Additionally, the average Constant score was 20 points lower than the contralateral shoulder and worse for bursal-sided tears. The detrimental effect of bursal-sided lesions was additionally noted by Cordasco et al., ${ }^{52}$ who evaluated 76 patients that had a debridement and acromioplasty for a PTRCT. After 53 months, failure was only observed in $3 \%$ of patients with articular-sided tears compared to $29 \%$ of those with a bursal-sided defect.

The variability of arthroscopic debridement has also been observed in the athletic population. For athletes under the age of 40 years who were treated with a subacromial decompression ( $60 \%$ had an acromioplasty), a satisfactory outcome was noted in $86 \%$ of acute traumatic cases with an overall $64 \%$ return to sport. ${ }^{53}$ 
Table I Clinical Outcome and Retear Rate Following Debridement +/- Acromioplasty of Partial Thickness Rotator Cuff Tears

\begin{tabular}{|c|c|c|c|c|}
\hline Study & $\begin{array}{l}\text { Number } \\
\text { of } \\
\text { Patients }\end{array}$ & Type of Repair & $\begin{array}{l}\text { Clinical Outcome Preoperative } \rightarrow \\
\text { Postoperative Follow-Up Score (Measure) }\end{array}$ & $\begin{array}{l}\text { Percentage of Repairs } \\
\text { Intact (Imaging Method) }\end{array}$ \\
\hline $\begin{array}{l}\text { Kartus et al } \\
(2006)^{51}\end{array}$ & 33 & $\begin{array}{l}\text { Subacromial decompression } \\
\text { without repair }\end{array}$ & Postoperative only: 65 (CS) & $\begin{array}{l}65 \% \text { intact ( } 26 \text { patients } \\
\text { available for MRI) }\end{array}$ \\
\hline $\begin{array}{l}\text { Dwyer et al } \\
(2018)^{47}\end{array}$ & 76 & $\begin{array}{l}\text { Bursal surface subacromial } \\
\text { decompression without repair } \\
\text { Articular surface subacromial } \\
\text { decompression without repair }\end{array}$ & $\begin{array}{l}46.16 \rightarrow 69.86 \text { (ASES) } \\
52.90 \rightarrow 85.90 \text { (RCMS) } \\
36.60 \rightarrow 67.34 \text { (Short WORC) } \\
40.33 \rightarrow 73.17 \text { (ASES) } \\
45.02 \rightarrow 77.09 \text { (RCMS) } \\
31.02 \rightarrow 65.54 \text { (Short WORC) }\end{array}$ & Not evaluated \\
\hline $\begin{array}{l}\text { Cordasco } \\
\text { et al } \\
(2002)^{52}\end{array}$ & 25 & $\begin{array}{l}<3 \mathrm{~mm} \text { deep tear } \\
\text { with subacromial decompression } \\
\text { without repair } \\
<6 \mathrm{~mm} \text { deep tear } \\
\text { with subacromial decompression } \\
\text { without repair }\end{array}$ & $\begin{array}{l}89 \text { (Postoperative L'Insalata) } \\
89 \text { (Postoperative L'Insalata) }\end{array}$ & Not evaluated \\
\hline $\begin{array}{l}\text { Ranebo } \\
\text { et } \mathrm{al}^{30}\end{array}$ & 45 & Acromioplasty without repair & $\begin{array}{l}\text { Postoperative only: I0I (CS) } \\
8 \text { I (WORC) }\end{array}$ & $\begin{array}{l}42 \% \text { developed tear } \\
\text { progression }\end{array}$ \\
\hline
\end{tabular}

Abbreviations: ASES, American Shoulder and Elbow Surgeons; CS, Constant score; WORC, Western Ontario Rotator Cuff Index; RCMS, Relative Constant-Murley score.

\section{Conversion to Full-Thickness Defect and Repair}

Conversion to a full thickness tear removes excess devitalised tissue and allows standard repair techniques to be utilised (Figure 1 and Table 2). Although this may be technically easier than some in situ repair techniques, removing native tendon tissue may alter the biomechanics of the rotator cuff. Moreover, resecting lateral tendon tissue may lead to a non-anatomic repair and length-tension mismatches. ${ }^{19}$ Nonetheless, encouraging results have been reported and are characterised by an improvement in range of movement, strength, pain, and function. ${ }^{54-56}$ Fama et al ${ }^{54}$ reviewed 87 patients who underwent conversion to a full thickness tear at a median follow-up of five years. Patient satisfaction was high and accompanied by a significant improvement in both the Constant score (53.5 to 94) and pain. Although similar results have been additionally been reported in other studies evaluating the results following full-thickness conversion, ${ }^{55-57}$ a recent prospect randomised controlled trial by Wang et $\mathrm{al}^{58}$ demonstrated no difference in patient-reported outcome measures and retear rates on MRI between isolated subacromial decompression and full-thickness conversion at 18 months follow-up.

\section{In situ Repair}

In situ transtendinous repair techniques are commonly performed on articular sided tears and preserve the lateral tendon tissue of the rotator cuff whilst restoring medial tendon-bone contact (Figure 2 and Table 3). ${ }^{7,59,60}$ Maintaining viable tissue in this manner has the theoretical advantage of permitting a more anatomical reconstruction of the enthesis. Zafra et al ${ }^{61}$ followed up 50 patients for a mean of 32.5 months who had either a single- or double-row in situ repair for a partial thickness tear. Both groups demonstrated an improvement in the ASES score, Constant score, and pain. No significant inter-group differences were noted and three retears were identified on MRI. Despite these encouraging results, the limitation of in situ repair is the risk of a tension mismatch between the articular and bursal sides due to over-tensioning, and the increased pain and stiffness that may result. ${ }^{12,62}$ For example, in a study of 489 consecutive rotator cuff repairs, Huberty et $\mathrm{al}^{62}$ determined that an in situ repair was a significant risk factor for the development of postoperative stiffness in the short-term. To mitigate this, further surgical techniques have been developed to perform an isolated reduction of the articular portion of the tendon. ${ }^{63}$ However, the advantage of this technique has not been demonstrated over other trans-tendon repairs. Overall, while good results can be obtained using in situ techniques, there 

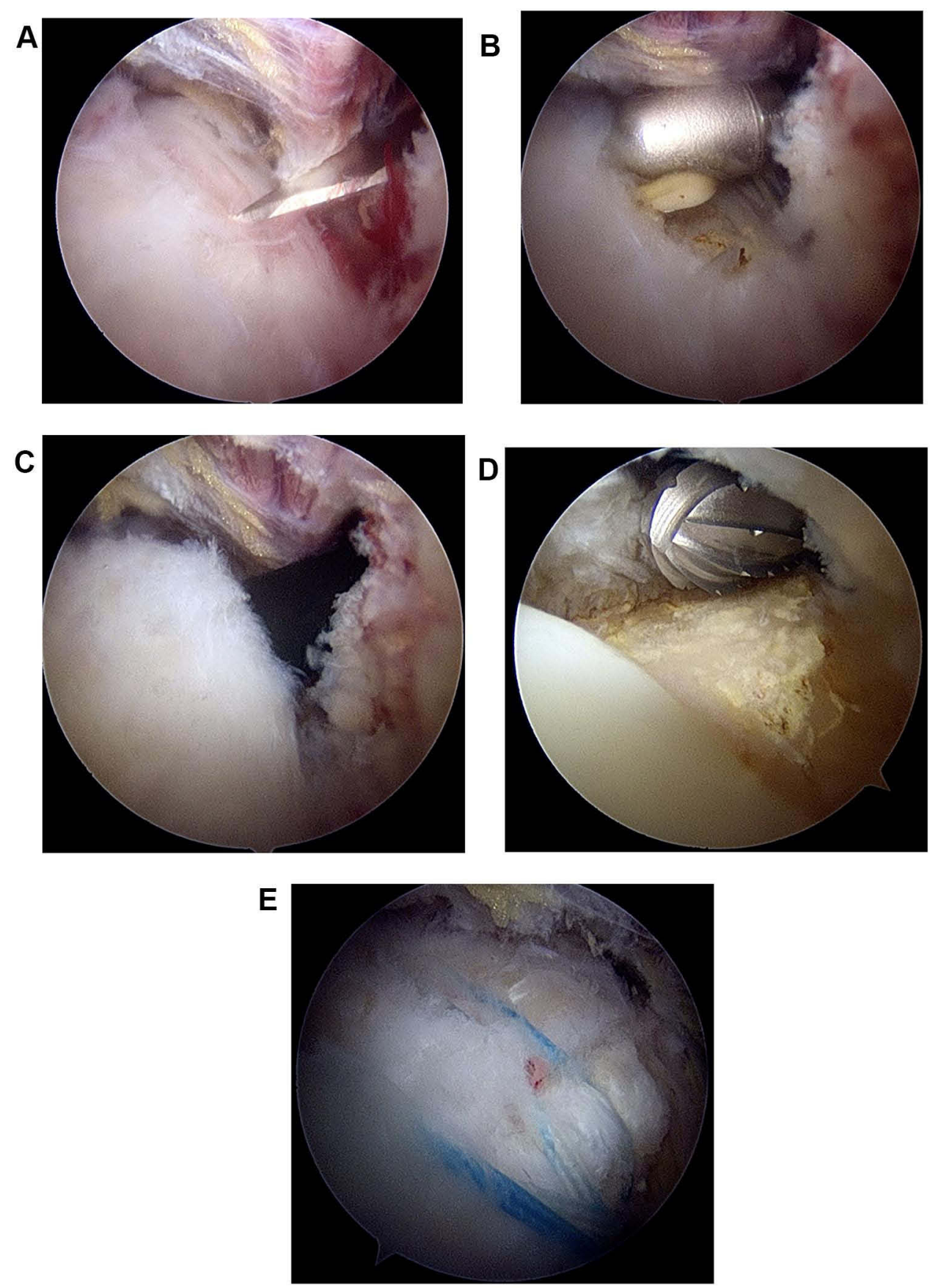

Figure I Right shoulder arthroscopy oriented in the beach chair position viewing from the posterior portal. (A) A bursal surface tear is identified within the subacromial space and converted into a full thickness tear using a knife inserted through a mid-lateral portal. (B) The tear is exposed using electrocautery. (C) The electrocautery device is inserted through the tear in the subacromial space so that it can be identified within the glenohumeral joint. (D) Footprint preparation is completed in the glenohumeral joint. (E) Rotator cuff repair is completed from within the subacromial space using a standard technique, such as the double row used here.

is an increase the risk of residual symptoms following surgery in patients with greater tendon retraction of the entire tendinous unit, advanced age, atraumatic history, and increased tendon retraction with minimal footprint exposure at surgery. ${ }^{64}$

\section{Conversion versus in situ Repairs}

In a cadaveric study comparing the biomechanical performance of transtendon in situ repair with tear completion and double-row repair, the in situ repair demonstrated significantly less gap formation and greater ultimate failure strength under cyclical loading conditions. ${ }^{19}$ Similar results were noted in an ovine model, with in situ repair resulting in the 
Table 2 Clinical Outcome and Retear Rate Following Conversion to a Full Thickness Defect and Subsequent Repair of a Partial Thickness Rotator Cuff Tears

\begin{tabular}{|c|c|c|c|c|}
\hline Study & $\begin{array}{l}\text { Number } \\
\text { of } \\
\text { Patients }\end{array}$ & Type of Repair & $\begin{array}{l}\text { Clinical Outcome Preoperative } \rightarrow \\
\text { Postoperative Follow-Up Score (Measure) }\end{array}$ & $\begin{array}{l}\text { Percentage of Repairs } \\
\text { Intact (Imaging Method) }\end{array}$ \\
\hline $\begin{array}{l}\text { Fukushi } \\
\text { et al } \\
(2020)^{57}\end{array}$ & 29 & Conversion & $\begin{array}{l}63.6 \rightarrow 90.8(\mathrm{JOA}) \\
51.1 \rightarrow 77.8(\mathrm{CS})\end{array}$ & $93 \%$ intact (MRI) \\
\hline $\begin{array}{l}\text { Zhang } \\
(2020)^{50}\end{array}$ & $\begin{array}{l}20 \\
26\end{array}$ & $\begin{array}{l}\text { Subacromial } \\
\text { decompression with tear } \\
\text { debridement } \\
\text { Conversion }\end{array}$ & $\begin{array}{l}\text { Significant improvement noted in both the ASES and } \\
\text { CS scores, but absolute values not provided }\end{array}$ & $\begin{array}{l}90 \% \text { intact }(\mathrm{MRI}) \\
100 \% \text { intact }(\mathrm{MRI})\end{array}$ \\
\hline $\begin{array}{l}\text { Kim et al } \\
(2013)^{56}\end{array}$ & 29 & $\begin{array}{l}\text { Bursal surface conversion } \\
\text { Articular surface } \\
\text { conversion }\end{array}$ & $\begin{array}{l}6.7 \rightarrow 1.4(\mathrm{VAS}) \\
14.7 \rightarrow 30.9(\mathrm{UCLA}) \\
36.1 \rightarrow 90.7(\mathrm{ASES}) \\
4.7 \rightarrow 10(\mathrm{SST}) \\
5.8 \rightarrow 0.9(\mathrm{VAS}) \\
15.7 \rightarrow 30.5(\mathrm{UCLA}) \\
42.4 \rightarrow 90.4(\mathrm{ASES}) \\
5.1 \rightarrow 9.7(\mathrm{SST})\end{array}$ & $\begin{array}{l}89 \% \text { intact (MRI) } \\
92 \% \text { intact (MRI) }\end{array}$ \\
\hline $\begin{array}{l}\text { Kim et al } \\
(2014)^{55}\end{array}$ & $\begin{array}{l}23 \\
20\end{array}$ & $\begin{array}{l}\text { Bursal surface conversion } \\
\text { Articular surface } \\
\text { conversion }\end{array}$ & $\begin{array}{l}55.83 \rightarrow 83(\mathrm{CS}) \\
19.09 \rightarrow 32.52(\mathrm{UCLA}) \\
46.6 \rightarrow 90.8(\mathrm{ASES}) \\
51 \rightarrow 75.85(\mathrm{CS}) \\
19.80 \rightarrow 32.70(\mathrm{UCLA}) \\
48.69 \rightarrow 91.80(\mathrm{ASES})\end{array}$ & $\begin{array}{l}89 \% \text { intact (MRI) } \\
92 \% \text { intact (MRI) }\end{array}$ \\
\hline $\begin{array}{l}\text { Fama et al } \\
(202 I)^{54}\end{array}$ & 87 & Conversion & $\begin{array}{l}53.5 \rightarrow 94(\mathrm{CS}) \\
8.6 \rightarrow 1 \text { (VAS) }\end{array}$ & $95.4 \%$ intact (MRI) \\
\hline $\begin{array}{l}\text { Wang et al } \\
(202 I)^{58}\end{array}$ & 43 & $\begin{array}{l}\text { Subacromial } \\
\text { decompression with tear } \\
\text { debridement } \\
\text { Conversion }\end{array}$ & $\begin{array}{l}5.77 \rightarrow 0.7 \mathrm{I}(\mathrm{VAS}) \\
39.5 \rightarrow 9 \mathrm{I}(\mathrm{CS}) \\
34 \rightarrow 92(\mathrm{ASES}) \\
13 \rightarrow 34(\mathrm{UCLA}) \\
5.49 \rightarrow 0.86(\mathrm{VAS}) \\
43.63 \rightarrow 91.77(\mathrm{CS}) \\
33.10 \rightarrow 93.63(\mathrm{ASES}) \\
12.58 \rightarrow 33.5 \mathrm{I}(\mathrm{UCLA})\end{array}$ & $\begin{array}{l}100 \% \text { intact (MRI) } \\
100 \% \text { intact (MRI) }\end{array}$ \\
\hline
\end{tabular}

Abbreviations: ASES, American Shoulder and Elbow Surgeons; JOA, Japanese Orthopaedic Association; CS, Constant score; SST, Simple shoulder test; VAS, Visual Analogue Scale; UCLA, University of California, Los Angeles Shoulder rating scale.

highest footprint contact pressures and ultimate load to failure. ${ }^{65}$ Alternatively, in a rabbit model comparing the two techniques, Pulatkan et $\mathrm{al}^{66}$ demonstrated that tear completion followed by repair led to a significantly greater load to failure and superior histological results. Despite these biomechanical advantages the results of clinical studies have been variable (Table 4). ${ }^{67-70}$

Castagna et $\mathrm{al}^{68}$ randomized 74 patients with an articular surface tear to undergo either an in situ repair or conversion to a full thickness defect and repair. At two years follow-up, there was an improvement in both the Constant score and visual analogue scale for pain in both groups, without any significant inter-group differences. In a further randomized study comparing these two surgical strategies, Shin et $\mathrm{al}^{69}$ similarly showed an improvement in clinical outcomes following surgery. In the tear completion group, functional recovery was faster, and pain was significantly less for the first three months following surgery. Although not significantly different, concerns though were raised regarding retears, 

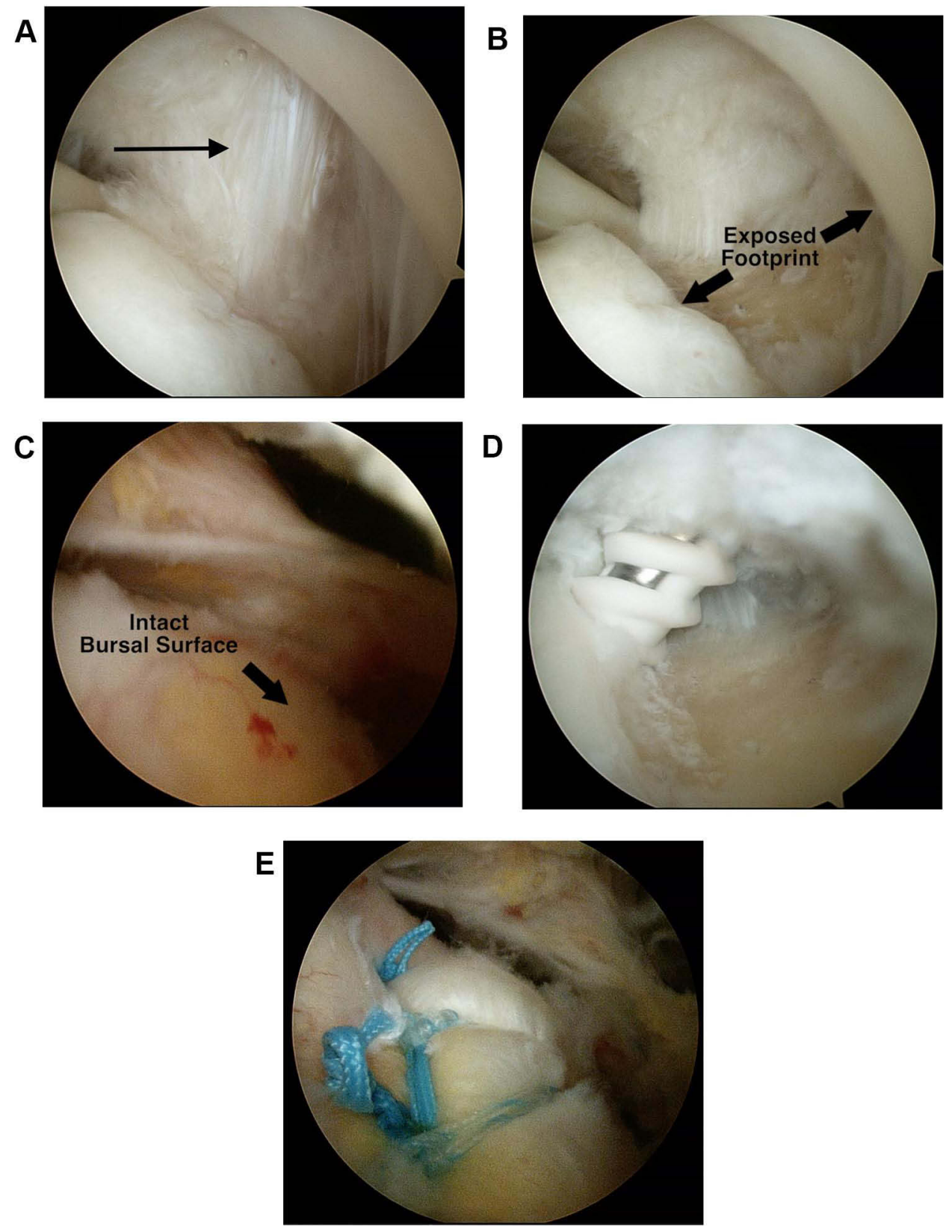

Figure 2 Right shoulder arthroscopy oriented in the beach chair position viewing through the posterior portal. (A) A partial thickness tear on the articular side is identified (black arrow) from within the glenohumeral joint. (B) The footprint is exposed after debriding the tear. (C) The intact bursal surface is seen from within the subacromial space. (D) A suture anchor is inserted transtendon through the rotator cuff into the medial aspect of the footprint, whilst viewing from the glenohumeral joint. (E) The sutures are tied from within the subacromial space, and in this case incorporated into a double row fixation construct.

which occurred in $8 \%(2 / 24)$ of the tear completion group and none from the in-situ repair group. In contrast, a further prospectively randomized study by Franceschi et $\mathrm{al}^{70}$ showed no significant difference between retear rates as observed on MRI.

\section{Biological Augmentation \\ Cell-Based Strategies}

Platelet-rich plasma (PRP) and stem cells are the two predominant cell-based strategies that have been specifically evaluated in the context of PTRCTs. ${ }^{71-74}$ PRP is one of the most common injectable agents for musculoskeletal disease and enhances the early phases of tissue healing by increasing the local concentration of platelets and growth factors such as platelet-derived 
Table 3 Clinical Outcome and Retear Rate Following Arthroscopic in situ Transtendinous Repair of a Partial Thickness Rotator Cuff Tears

\begin{tabular}{|c|c|c|c|c|}
\hline Study & $\begin{array}{l}\text { Number of } \\
\text { Patients }\end{array}$ & $\begin{array}{l}\text { Type of } \\
\text { Repair }\end{array}$ & $\begin{array}{l}\text { Clinical Outcome Preoperative } \rightarrow \text { Postoperative } \\
\text { Follow-Up Score (Measure) }\end{array}$ & $\begin{array}{l}\text { Percentage of Repairs Intact } \\
\text { (Imaging Method) }\end{array}$ \\
\hline $\begin{array}{l}\text { Prasetia et al } \\
(2020)^{59}\end{array}$ & $\begin{array}{c}\text { Medial } \\
\text { anchorless } \\
\text { Medial anchor }\end{array}$ & $\begin{array}{l}\text { In Situ } \\
\text { Repair }\end{array}$ & $\begin{array}{l}28.1 \rightarrow 91.9(\text { ASES) } \\
9 \rightarrow 1 \text { (VAS) } \\
32.9 \rightarrow 91.3(\text { ASES) } \\
8 \rightarrow 1 \text { (VAS) }\end{array}$ & $96 \%$ intact (MRI) \\
\hline $\begin{array}{l}\text { Rossi et al } \\
(2019)^{60}\end{array}$ & 80 & $\begin{array}{l}\text { In Situ } \\
\text { Repair }\end{array}$ & $45.6 \rightarrow 85.1$ (ASES) & Not evaluated \\
\hline $\begin{array}{l}\text { Zafra et al } \\
(2020)^{61}\end{array}$ & 50 & $\begin{array}{l}\text { In Situ } \\
\text { Repair }\end{array}$ & $\begin{array}{l}\text { Single row repair: } \\
35.9 \rightarrow 96.7 \text { (ASES) } \\
55.6 \rightarrow 97.8(\mathrm{CS}) \\
\text { Double row repair: } \\
35.3 \rightarrow 93.4 \text { (ASES) } \\
57.6 \rightarrow 97.3(\mathrm{CS})\end{array}$ & $94 \%$ intact (MRI) \\
\hline
\end{tabular}

Abbreviations: ASES, American Shoulder and Elbow Surgeons; CS, Constant score; VAS, Visual Analogue Scale.

Table 4 Clinical Outcome and Retear Rate Following a Comparison Between Transtendon in situ Repair and Tear Completion with Subsequent Repair, for Partial Thickness Rotator Cuff Tears

\begin{tabular}{|c|c|c|c|c|}
\hline Study & $\begin{array}{l}\text { Number of } \\
\text { Patients }\end{array}$ & $\begin{array}{l}\text { Type of } \\
\text { Repair }\end{array}$ & $\begin{array}{l}\text { Clinical Outcome Preoperative } \rightarrow \text { Postoperative } \\
\text { Follow-Up Score (Measure) }\end{array}$ & $\begin{array}{l}\text { Percentage of Repairs Intact } \\
\text { (Imaging Method) }\end{array}$ \\
\hline $\begin{array}{l}\text { Shin et al } \\
(2015)^{67}\end{array}$ & 47 & $\begin{array}{l}\text { In Situ Repair } \\
\text { Conversion }\end{array}$ & $\begin{array}{l}45.4 \rightarrow 88.6(\text { ASES) } \\
66.9 \rightarrow 88.1(\mathrm{CS}) \\
5.3 \rightarrow 0.9(\mathrm{VAS}) \\
50.1 \rightarrow 93.4(\mathrm{ASES}) \\
62.8 \rightarrow 89.4(\mathrm{CS}) \\
5.3 \rightarrow 0.9(\mathrm{VAS})\end{array}$ & $\begin{array}{l}91.5 \% \text { intact (MRI) } \\
91.9 \text { intact (MRI) }\end{array}$ \\
\hline $\begin{array}{l}\text { Shin } \\
(2012)^{69}\end{array}$ & 24 & $\begin{array}{l}\text { In Situ Repair } \\
\text { Conversion }\end{array}$ & $\begin{array}{l}50.8 \rightarrow 89.1(\mathrm{ASES}) \\
54.8 \rightarrow 84.8(\mathrm{CS}) \\
49.2 \rightarrow 86.2(\mathrm{ASES}) \\
59 \rightarrow 87.1(\mathrm{CS})\end{array}$ & $\begin{array}{l}100 \% \text { intact (MRI) } \\
92 \% \text { intact (MRI) }\end{array}$ \\
\hline $\begin{array}{l}\text { Franceschi } \\
(2013)^{70}\end{array}$ & $\begin{array}{l}32 \\
28\end{array}$ & $\begin{array}{l}\text { In Situ Repair } \\
\text { Conversion }\end{array}$ & $\begin{array}{l}45.6 \rightarrow 91(\mathrm{ASES}) \\
48 \rightarrow 92(\mathrm{CS}) \\
47 \rightarrow 90(\mathrm{ASES}) \\
46 \rightarrow 91(\mathrm{CS})\end{array}$ & $\begin{array}{l}97 \% \text { intact (MRI) } \\
96 \% \text { intact (MRI) }\end{array}$ \\
\hline $\begin{array}{l}\text { Castagna } \\
(2015)^{68}\end{array}$ & $\begin{array}{l}37 \\
37\end{array}$ & $\begin{array}{l}\text { In Situ Repair } \\
\text { Conversion }\end{array}$ & $\begin{array}{l}\text { Improvement by a mean value of } 25 . \text { (CS) } \\
\text { Improvement by a mean value of } 3.4 \text { (VAS) } \\
\text { Improvement by a mean value of } 29 \text { (CS) } \\
\text { Improvement by a mean value of } 3.6 \text { (VAS) }\end{array}$ & Not evaluated \\
\hline
\end{tabular}

Abbreviations: ASES, American Shoulder and Elbow Surgeons; CS, Constant score; VAS, Visual Analogue Scale.

growth factor, vascular-derived growth factor, transforming growth factor $\beta$, and epidermal growth factor. ${ }^{75}$ In a double-blind randomized controlled trial, Kwong et $\mathrm{al}^{71}$ compared PRP to corticosteroid injections for PTRCTs. At three months after injection, the PRP group had greater improvement in their VAS and WORC scores. This benefit was not sustained at 12 months, and no difference was noted in either the failure rate or rate of conversion to surgery between groups. Cai et al ${ }^{73}$ combined PRP with sodium hyaluronate (SH) for the treatment of partial thickness tears and found that this yielded better results (higher Constant, ASES and VAS scores) than either of the treatments in isolation. Additionally, MRI showed that the 
tear size significantly decreased in size in both the PRP and SH + PRP groups. In a recent meta-analysis of all randomized controlled trials evaluating PRP as a non-operative treatment for rotator cuff tears, there was limited evidence to advocate its widespread use because in the short-term it was not efficacious, and did not result in better outcomes (functional outcome, pain scores, and range of motion) when compared to an exercise regime. ${ }^{76}$

Stem cell treatment for rotator cuff tears is a promising development because they have been shown to result in an anti-inflammatory response, improved tendon regeneration, optimised collagen fibre arrangement, higher load-to-failure, and higher tensile strength. ${ }^{77-79}$ Hurd et $\mathrm{al}^{74}$ carried out a randomized controlled pilot study to compare the effects of adipose-derived regenerative cells (ADRCs) and corticosteroid injections on PTRCTs. At one-year follow-up, there were no adverse reactions and the ADRC group demonstrated a significantly higher ASES score. In a non-randomized controlled trial comparing the effects of an exercise regime to PRP combined with bone marrow aspirate (BMACPRP complex) on PTRCTs, the experimental group demonstrated a significantly greater improvement in VAS and ASES scores compared to controls at three months. Tear size decreased after BMAC-PRP injection although this did not significantly differ from controls. ${ }^{72}$

\section{Scaffolds}

Due to some variable results associated with current surgical strategies as well as the restrictive post-operative rehabilitation that is often required, increased attention has been given to biological adjuncts. Bioinductive collagen implants have been shown in an ovine study to induce the formation of well-organized collagen fibres oriented in the direction of load and a fibrocartilaginous transition across the enthesis. ${ }^{80}$ Although the graft had resorbed by six months with no adverse reactions, this was accompanied by an additional $2.5 \mathrm{~mm}$ of new tissue growth compared to controls. Finite-element analysis has revealed that by increasing the thickness of the supraspinatus tendon by $2 \mathrm{~mm}$ on the bursal surface, the peak intra-tendinous strain can be decreased by $47 \%$ in bursal-sided partial-thickness tears and by $40 \%$ in articular-sided partial-thickness tears. ${ }^{81}$

Clinical studies evaluating this scaffold demonstrate a significant improvement in pain, functional outcome, with a corresponding increased tendon thickness and favourable safety profile. ${ }^{13,82-84}$ Importantly, an accelerated rehabilitation programme can be used with few restrictions, particularly if an isolated bioinductive collagen implant is utilized without a concomitant repair. ${ }^{82}$ Although this biomaterial has provided encouraging results in the short-term, it must be rigorously compared to the more cost-effective options outlined above (subacromial decompression, in situ repair, and conversion to a full-thickness defect and repair) before it can be recommended for routine clinical use.

\section{Influence of Tear Location (Articular vs Bursal) on Clinical Outcomes}

The articular surface of the rotator cuff has an ultimate stress to failure that is approximately half that of its corresponding bursal side, with thinner and less uniformly arranged collagen fibres. ${ }^{23}$ Intrinsic degenerative changes, that often occur with increasing age, have therefore been suggested to represent the predominant factor contributing to the occurrence of articular-sided tears. Bursal-sided tears alternatively, have traditionally been thought to arise from extrinsic mechanical impingement from a subacromial spur emanating from the coracoacromial ligament, although little evidence exists to support this theory. ${ }^{1,41}$ Based on their differing aetiologies, it has been speculated that a difference could exist in the clinical outcomes between articular- and bursal-sided PTRCTs. In a recent retrospective comparative study though, no difference was demonstrated in clinical outcomes (range of motion, pain, outcome scoring) between articular- and bursalsided tears. ${ }^{85}$

\section{Conclusions}

Partial thickness tears of the rotator cuff are a common cause of shoulder pain and disability. Surgery is confined to those experiencing severe symptoms despite non-operative measures, and for tears involving greater than $50 \%$ thickness. A number of surgical strategies have been described, but there is insufficient evidence to advocate one repair technique over another. Future research should focus on determining the most effective surgical solution (subacromial decompression versus conversion to full thickness tear and repair versus in situ repair) and explore the precise role of biological approaches (eg bioinductive collagen implants and cell-based strategies). 


\section{Disclosure}

The authors report no conflicts of interest in this work.

\section{References}

1. Matava MJ, Purcell DB, Rudzki JR. Partial-thickness rotator cuff tears. Am J Sports Med. 2005;33(9):1405-1417. doi:10.1177/0363546505280213

2. Teunis T, Lubberts B, Reilly BT, Ring D. A systematic review and pooled analysis of the prevalence of rotator cuff disease with increasing age. J Shoulder Elbow Surg. 2014;23(12):1913-1921. doi:10.1016/j.jse.2014.08.001

3. Fukuda H. Partial-thickness rotator cuff tears: a modern view on Codman's classic. J Shoulder Elbow Surg. 2000;9(2):163-168. doi:10.1067/ mse.2000.101959

4. Sano H, Ishii H, Trudel G, Uhthoff HK. Histologic evidence of degeneration at the insertion of 3 rotator cuff tendons: a comparative study with human cadaveric shoulders. J Shoulder Elbow Surg. 1999;8(6):574-579. doi:10.1016/S1058-2746(99)90092-7

5. Lohr JF, Uhthoff HK. The microvascular pattern of the supraspinatus tendon. Clin Orthop Relat Res. 1990;(254):35-38.

6. Sher JS, Uribe JW, Posada A, Murphy BJ, Zlatkin MB. Abnormal findings on magnetic resonance images of asymptomatic shoulders. J Bone Joint Surg Am. 1995;77(1):10-15. doi:10.2106/00004623-199501000-00002

7. Matthewson G, Beach CJ, Nelson AA, et al. Partial thickness rotator cuff tears: current concepts. Adv Orthop. 2015;2015:458786. doi:10.1155/ $2015 / 458786$

8. Lo IK, Denkers MR, More KD, Nelson AA, Thornton GM, Boorman RS. Partial-thickness rotator cuff tears: clinical and imaging outcomes and prognostic factors of successful nonoperative treatment. Open Access J Sports Med. 2018;9:191-197. doi:10.2147/OAJSM.S153236

9. Keener JD, Galatz LM, Teefey SA, et al. A prospective evaluation of survivorship of asymptomatic degenerative rotator cuff tears. $J$ Bone Joint Surg Am. 2015;97(2):89-98. doi:10.2106/JBJS.N.00099

10. Mazzocca AD, Rincon LM, O'Connor RW, et al. Intra-articular partial-thickness rotator cuff tears: analysis of injured and repaired strain behavior. Am J Sports Med. 2008;36(1):110-116. doi:10.1177/0363546507307502

11. Lo IK, Burkhart SS. Transtendon arthroscopic repair of partial-thickness, articular surface tears of the rotator cuff. Arthroscopy. 2004;20 (2):214-220. doi:10.1016/j.arthro.2003.11.042

12. Jordan RW, Bentick K, Saithna A. Transtendinous repair of partial articular sided supraspinatus tears is associated with higher rates of stiffness and significantly inferior early functional scores than tear completion and repair: a systematic review. Orthopaed Traumatol Surg Res. 2018;104 (6):829-837. doi:10.1016/j.otsr.2018.06.007

13. Schlegel TF, Abrams JS, Bushnell BD, Brock JL, Ho CP. Radiologic and clinical evaluation of a bioabsorbable collagen implant to treat partial-thickness tears: a prospective multicenter study. J Shoulder Elbow Surg. 2018;27(2):242-251. doi:10.1016/j.jse.2017.08.023

14. Fukuda H. The management of partial-thickness tears of the rotator cuff. J Bone Joint Surg Br. 2003;85(1):3-11. doi:10.1302/0301620X.85B1.13846

15. Ozaki J, Fujimoto S, Nakagawa Y, Masuhara K, Tamai S. Tears of the rotator cuff of the shoulder associated with pathological changes in the acromion. A study in cadavera. J Bone Joint Surg Am. 1988;70(8):1224-1230. doi:10.2106/00004623-198870080-00015

16. Bey MJ, Ramsey ML, Soslowsky LJ. Intratendinous strain fields of the supraspinatus tendon: effect of a surgically created articular-surface rotator cuff tear. J Shoulder Elbow Surg. 2002;11(6):562-569. doi:10.1067/mse.2002.126767

17. Rudzki JR, Adler RS, Warren RF, et al. Contrast-enhanced ultrasound characterization of the vascularity of the rotator cuff tendon: age- and activity-related changes in the intact asymptomatic rotator cuff. J Shoulder Elbow Surg. 2008;17(1 Suppl):96s-100s. doi:10.1016/j.jse.2007.07.004

18. Neer CS. Anterior acromioplasty for the chronic impingement syndrome in the shoulder: a preliminary report. J Bone Joint Surg Am. 1972;54 (1):41-50. doi:10.2106/00004623-197254010-00003

19. Gonzalez-Lomas G, Kippe MA, Brown GD, et al. In situ transtendon repair outperforms tear completion and repair for partial articular-sided supraspinatus tendon tears. J Shoulder Elbow Surg. 2008;17(5):722-728. doi:10.1016/j.jse.2008.01.148

20. Davidson PA, Elattrache NS, Jobe CM, Jobe FW. Rotator cuff and posterior-superior glenoid labrum injury associated with increased glenohumeral motion: a new site of impingement. J Shoulder Elbow Surg. 1995;4(5):384-390. doi:10.1016/S1058-2746(95)80023-9

21. Park HB, Gwark JY, Im JH, Jung J, Na JB, Yoon CH. Factors associated with atraumatic posterosuperior rotator cuff tears. J Bone Joint Surg Am. 2018;100(16):1397-1405. doi:10.2106/JBJS.16.01592

22. Dabija DI, Gao C, Edwards TL, Kuhn JE, Jain NB. Genetic and familial predisposition to rotator cuff disease: a systematic review. $J$ Shoulder Elbow Surg. 2017;26(6):1103-1112. doi:10.1016/j.jse.2016.11.038

23. Nakajima T, Rokuuma N, Hamada K, Tomatsu T, Fukuda H. Histologic and biomechanical characteristics of the supraspinatus tendon: reference to rotator cuff tearing. J Shoulder Elbow Surg. 1994;3(2):79-87. doi:10.1016/S1058-2746(09)80114-6

24. Clark JM, Harryman DT. Tendons, ligaments, and capsule of the rotator cuff. Gross and microscopic anatomy. J Bone Joint Surg Am. 1992;74 (5):713-725. doi:10.2106/00004623-199274050-00010

25. Reilly P, Amis AA, Wallace AL, Emery RJ. Supraspinatus tears: propagation and strain alteration. J Shoulder Elbow Surg. 2003;12(2):134-138. doi: $10.1067 / \mathrm{mse} .2003 .7$

26. Sano H, Wakabayashi I, Itoi E. Stress distribution in the supraspinatus tendon with partial-thickness tears: an analysis using two-dimensional finite element model. J Shoulder Elbow Surg. 2006;15(1):100-105. doi:10.1016/j.jse.2005.04.003

27. Smith MM, Sakurai G, Smith SM, et al. Modulation of aggrecan and ADAMTS expression in ovine tendinopathy induced by altered strain. Arthrit Rheumat. 2008;58(4):1055-1066. doi:10.1002/art.23388

28. Yang S, Park HS, Flores S, et al. Biomechanical analysis of bursal-sided partial thickness rotator cuff tears. J Shoulder Elbow Surg. 2009;18 (3):379-385. doi:10.1016/j.jse.2008.12.011

29. Yamanaka K, Matsumoto T. The joint side tear of the rotator cuff. A followup study by arthrography. Clin Orthop Relat Res. 1994;(304):68-73.

30. Ranebo MC, Björnsson Hallgren HC, Norlin R, Adolfsson LE. Clinical and structural outcome 22 years after acromioplasty without tendon repair in patients with subacromial pain and cuff tears. J Shoulder Elbow Surg. 2017;26(7):1262-1270. doi:10.1016/j.jse.2016.11.012

31. Fukuda H, Hamada K, Nakajima T, Yamada N, Tomonaga A, Goto M. Partial-thickness tears of the rotator cuff. A clinicopathological review based on 66 surgically verified cases. Int Orthop. 1996;20(4):257-265. doi:10.1007/s002640050075 
32. Wolff AB, Sethi P, Sutton KM, Covey AS, Magit DP, Medvecky M. Partial-thickness rotator cuff tears. J Am Acad Orthop Surg. 2006;14 (13):715-725. doi:10.5435/00124635-200612000-00003

33. Hamada K, Tomonaga A, Gotoh M, Yamakawa H, Fukuda H. Intrinsic healing capacity and tearing process of torn supraspinatus tendons: in situ hybridization study of alpha 1 (I) procollagen mRNA. J Orthopaed Res. 1997;15(1):24-32. doi:10.1002/jor.1100150105

34. Ellman H. Diagnosis and treatment of incomplete rotator cuff tears. Clin Orthop Relat Res. 1990;(254):64-74.

35. Spencer EE, Dunn WR, Wright RW, et al. Interobserver agreement in the classification of rotator cuff tears using magnetic resonance imaging. Am J Sports Med. 2008;36(1):99-103. doi:10.1177/0363546507307504

36. Kuhn JE, Dunn WR, Ma B, et al. Interobserver agreement in the classification of rotator cuff tears. Am J Sports Med. 2007;35(3):437-441. doi:10.1177/0363546506298108

37. Liu JN, Garcia GH, Gowd AK, et al. Treatment of partial thickness rotator cuff tears in overhead athletes. Curr Rev Musculoskelet Med. 2018;11 (1):55-62. doi:10.1007/s12178-018-9459-2

38. Fukuda H, Hamada K, Nakajima T, Tomonaga A. Pathology and pathogenesis of the intratendinous tearing of the rotator cuff viewed from en bloc histologic sections. Clin Orthop Relat Res. 1994;(304):60-67.

39. Millstein ES, Snyder SJ. Arthroscopic management of partial, full-thickness, and complex rotator cuff tears: indications, techniques, and complications. Arthroscopy. 2003;19(Suppl 1):189-199. doi:10.1016/j.arthro.2003.10.033

40. Conway JE. Arthroscopic repair of partial-thickness rotator cuff tears and SLAP lesions in professional baseball players. Orthop Clin North Am. 2001;32(3):443-456. doi:10.1016/S0030-5898(05)70213-3

41. Papadonikolakis A, McKenna M, Warme W, Martin BI, Matsen FA. Published evidence relevant to the diagnosis of impingement syndrome of the shoulder. J Bone Joint Surg Am. 2011;93(19):1827-1832. doi:10.2106/JBJS.J.01748

42. Desai VS, Camp CL, Boddapati V, Dines JS, Brockmeier SF, Werner BC. Increasing numbers of shoulder corticosteroid injections within a year preoperatively may be associated with a higher rate of subsequent revision rotator cuff surgery. Arthroscopy. 2019;35(1):45-50. doi:10.1016/j. arthro.2018.07.043

43. Yamaguchi K, Tetro AM, Blam O, Evanoff BA, Teefey SA, Middleton WD. Natural history of asymptomatic rotator cuff tears: a longitudinal analysis of asymptomatic tears detected sonographically. J Shoulder Elbow Surg. 2001;10(3):199-203. doi:10.1067/mse.2001.113086

44. Maman E, Harris C, White L, Tomlinson G, Shashank M, Boynton E. Outcome of nonoperative treatment of symptomatic rotator cuff tears monitored by magnetic resonance imaging. J Bone Joint Surg Am. 2009;91(8):1898-1906. doi:10.2106/JBJS.G.01335

45. Weber SC. Arthroscopic debridement and acromioplasty versus mini-open repair in the treatment of significant partial-thickness rotator cuff tears. Arthroscopy. 1999;15(2):126-131. doi:10.1053/ar.1999.v15.0150121

46. Prasetia R, Kholinne E, Suvarly P, et al. High-grade bursal side rotator-cuff repair: a surgical outcome review. Orthop Res Rev. 2021;13:179-186. doi:10.2147/ORR.S323092

47. Dwyer T, Razmjou H, Henry P, Misra S, Maman E, Holtby R. Short-term outcomes of arthroscopic debridement and selected acromioplasty of bursal- vs articular-sided partial-thickness rotator cuff tears of less than 50. Orthop J Sports Med. 2018;6(8):2325967118792001. doi:10.1177/ 2325967118792001

48. Budoff JE, Rodin D, Ochiai D, Nirschl RP. Arthroscopic rotator cuff debridement without decompression for the treatment of tendinosis. Arthroscopy. 2005;21(9):1081-1089. doi:10.1016/j.arthro.2005.05.019

49. Reynolds SB, Dugas JR, Cain EL, McMichael CS, Andrews JR. Débridement of small partial-thickness rotator cuff tears in elite overhead throwers. Clin Orthop Relat Res. 2008;466(3):614-621. doi:10.1007/s11999-007-0107-1

50. Zhang Y, Zhai S, Qi C, et al. A comparative study of arthroscopic débridement versus repair for Ellman grade II bursal-side partial-thickness rotator cuff tears. J Shoulder Elbow Surg. 2020;29(10):2072-2079. doi:10.1016/j.jse.2020.03.006

51. Kartus J, Kartus C, Rostgård-Christensen L, Sernert N, Read J, Perko M. Long-term clinical and ultrasound evaluation after arthroscopic acromioplasty in patients with partial rotator cuff tears. Arthroscopy. 2006;22(1):44-49. doi:10.1016/j.arthro.2005.07.027

52. Cordasco FA, Backer M, Craig EV, Klein D, Warren RF. The partial-thickness rotator cuff tear: is acromioplasty without repair sufficient? Am J Sports Med. 2002;30(2):257-260. doi:10.1177/03635465020300021801

53. Payne LZ, Altchek DW, Craig EV, Warren RF. Arthroscopic treatment of partial rotator cuff tears in young athletes. A preliminary report. Am J Sports Med. 1997;25(3):299-305. doi:10.1177/036354659702500305

54. Fama G, Tagliapietra J, Belluzzi E, Pozzuoli A, Biz C, Ruggieri P. Mid-term outcomes after arthroscopic "tear completion repair" of partial thickness rotator cuff tears. Medicina (Kaunas). 2021;57(1). doi:10.3390/medicina57010074

55. Kim KC, Shin HD, Cha SM, Park JY. Repair integrity and functional outcome after arthroscopic conversion to a full-thickness rotator cuff tear: articular- versus bursal-side partial tears. Am J Sports Med. 2014;42(2):451-456. doi:10.1177/0363546513512770

56. Kim SJ, Kim SH, Lim SH, Chun YM. Use of magnetic resonance arthrography to compare clinical features and structural integrity after arthroscopic repair of bursal versus articular side partial-thickness rotator cuff tears. Am J Sports Med. 2013;41(9):2041-2047. doi:10.1177/ 0363546513496214

57. Fukushi R, Horigome K, Yamashita T. Clinical outcomes following arthroscopic repair of articular vs. bursal partial-thickness rotator cuff tears with follow-up of 2 years or more. JSES Int. 2020;4(2):352-356. doi:10.1016/j.jseint.2019.12.002

58. Wang T, Ren Z, Zhang Y, et al. Comparison of arthroscopic debridement and repair in the treatment of Ellman grade II bursal-side partial-thickness rotator cuff tears: a prospective randomized controlled trial. Orthop Surg. 2021;13(7):2070-2080. doi:10.1111/os.13130

59. Prasetia R, Sukhapradit B, Chernchujit B. Clinical features and repair integrity after knotless - In situ suture bridge technique in high-grade bursal side rotator cuff tears. J Orthop. 2020;20:352-358. doi:10.1016/j.jor.2020.06.019

60. Rossi LA, Atala NA, Bertona A, et al. Long-term outcomes after in situ arthroscopic repair of partial rotator cuff tears. Arthroscopy. 2019;35 (3):698-702. doi:10.1016/j.arthro.2018.09.026

61. Zafra M, Uceda P, Muñoz-Luna F, Muñoz-López RC, Font P. Arthroscopic repair of partial-thickness articular surface rotator cuff tears: single-row transtendon technique versus double-row suture bridge (transosseous equivalent) fixation: results from a prospective randomized study. Arch Orthop Trauma Surg. 2020;140(8):1065-1071. doi:10.1007/s00402-020-03387-6

62. Huberty DP, Schoolfield JD, Brady PC, Vadala AP, Arrigoni P, Burkhart SS. Incidence and treatment of postoperative stiffness following arthroscopic rotator cuff repair. Arthroscopy. 2009;25(8):880-890. doi:10.1016/j.arthro.2009.01.018 
63. Brockmeier SF, Dodson CC, Gamradt SC, Coleman SH, Altchek DW. Arthroscopic intratendinous repair of the delaminated partial-thickness rotator cuff tear in overhead athletes. Arthroscopy. 2008;24(8):961-965. doi:10.1016/j.arthro.2007.08.016

64. Castagna A, Delle Rose G, Conti M, Snyder SJ, Borroni M, Garofalo R. Predictive factors of subtle residual shoulder symptoms after transtendinous arthroscopic cuff repair: a clinical study. Am J Sports Med. 2009;37(1):103-108. doi:10.1177/0363546508324178

65. Peters KS, Lam PH, Murrell GA. Repair of partial-thickness rotator cuff tears: a biomechanical analysis of footprint contact pressure and strength in an ovine model. Arthroscopy. 2010;26(7):877-884. doi:10.1016/j.arthro.2010.04.007

66. Pulatkan A, Anwar W, Ayık O, et al. Tear completion versus in situ repair for 50\% partial-thickness bursal-side rotator cuff tears: a biomechanical and histological study in an animal model. Am J Sports Med. 2020;48(8):1818-1825. doi:10.1177/0363546520909854

67. Shin SJ, Kook SH, Rao N, Seo MJ. Clinical outcomes of modified Mason-Allen single-row repair for bursal-sided partial-thickness rotator cuff tears: comparison with the double-row suture-bridge technique. Am J Sports Med. 2015;43(8):1976-1982. doi:10.1177/0363546515587718

68. Castagna A, Borroni M, Garofalo R, et al. Deep partial rotator cuff tear: transtendon repair or tear completion and repair? A randomized clinical trial. Knee Surg Sports Traumatol Arthrosc. 2015;23(2):460-463. doi:10.1007/s00167-013-2536-6

69. Shin SJ. A comparison of 2 repair techniques for partial-thickness articular-sided rotator cuff tears. Arthroscopy. 2012;28(1):25-33. doi:10.1016/j. arthro.2011.07.005

70. Franceschi F, Papalia R, Del Buono A, et al. Articular-sided rotator cuff tears: which is the best repair? A three-year prospective randomised controlled trial. Int Orthop. 2013;37(8):1487-1493. doi:10.1007/s00264-013-1882-9

71. Kwong CA, Woodmass JM, Gusnowski EM, et al. Platelet-rich plasma in patients with partial-thickness rotator cuff tears or tendinopathy leads to significantly improved short-term pain relief and function compared with corticosteroid injection: a double-blind randomized controlled trial. Arthroscopy. 2021;37(2):510-517. doi:10.1016/j.arthro.2020.10.037

72. Kim SJ, Kim EK, Kim SJ, Song DH. Effects of bone marrow aspirate concentrate and platelet-rich plasma on patients with partial tear of the rotator cuff tendon. J Orthop Surg Res. 2018;13(1):1. doi:10.1186/s13018-017-0693-x

73. Cai YU, Sun Z, Liao B, Song Z, Xiao T, Zhu P. Sodium hyaluronate and platelet-rich plasma for partial-thickness rotator cuff tears. Med Sci Sports Exerc. 2019;51(2):227-233. doi:10.1249/MSS.0000000000001781

74. Hurd JL, Facile TR, Weiss J, et al. Safety and efficacy of treating symptomatic, partial-thickness rotator cuff tears with fresh, uncultured, unmodified, autologous adipose-derived regenerative cells (UA-ADRCs) isolated at the point of care: a prospective, randomized, controlled first-inhuman pilot study. J Orthop Surg Res. 2020;15(1):122. doi:10.1186/s13018-020-01631-8

75. Hudgens JL, Sugg KB, Grekin JA, Gumucio JP, Bedi A, Mendias CL. Platelet-rich plasma activates proinflammatory signaling pathways and induces oxidative stress in tendon fibroblasts. Am J Sports Med. 2016;44(8):1931-1940. doi:10.1177/0363546516637176

76. Hurley ET, Hannon CP, Pauzenberger L, Fat DL, Moran CJ, Mullett H. Nonoperative treatment of rotator cuff disease with platelet-rich plasma: a systematic review of randomized controlled trials. Arthroscopy. 2019;35(5):1584-1591. doi:10.1016/j.arthro.2018.10.115

77. Thangarajah T, Shahbazi S, Pendegrass CJ, Lambert S, Alexander S, Blunn GW. Tendon reattachment to bone in an ovine tendon defect model of retraction using allogenic and xenogenic demineralised bone matrix incorporated with mesenchymal stem cells. PLoS One. 2016;11(9):e0161473. doi:10.1371/journal.pone.0161473

78. Thangarajah T, Sanghani-Kerai A, Henshaw F, Lambert SM, Pendegrass CJ, Blunn GW. Application of a demineralized cortical bone matrix and bone marrow-derived mesenchymal stem cells in a model of chronic rotator cuff degeneration. Am J Sports Med. 2018;46(1):98-108. doi:10.1177/ 0363546517727512

79. Chen HS, Su YT, Chan TM, et al. Human adipose-derived stem cells accelerate the restoration of tensile strength of tendon and alleviate the progression of rotator cuff injury in a rat model. Cell Transplant. 2015;24(3):509-520. doi:10.3727/096368915X686968

80. Van Kampen C, Arnoczky S, Parks P, et al. Tissue-engineered augmentation of a rotator cuff tendon using a reconstituted collagen scaffold: a histological evaluation in sheep. Muscles Ligaments Tendons J. 2013;3(3):229-235. doi:10.32098/mltj.03.2013.17

81. Chen Q. Two-dimensional finite element proof-of-concept modeling on rotator cuff tear scaffold efficacy. Technical report from the material and structural testing core, Mayo Clinic, Rochester, Minnesota. 2011.

82. Bokor DJ, Sonnabend D, Deady L, et al. Evidence of healing of partial-thickness rotator cuff tears following arthroscopic augmentation with a collagen implant: a 2-year MRI follow-up. Muscles Ligaments Tendons J. 2016;6(1):16-25. doi:10.32098/mltj.01.2016.03

83. Schlegel TF, Abrams JS, Angelo RL, Getelman MH, Ho CP, Bushnell BD. Isolated bioinductive repair of partial-thickness rotator cuff tears using a resorbable bovine collagen implant: two-year radiologic and clinical outcomes from a prospective multicenter study. J Shoulder Elbow Surg. 2020;30:1938-1948.

84. McIntyre LF, Bishai SK, Brown PB, Bushnell BD, Trenhaile SW. Patient-reported outcomes after use of a bioabsorbable collagen implant to treat partial and full-thickness rotator cuff tears. Arthroscopy. 2019;35(8):2262-2271. doi:10.1016/j.arthro.2019.02.019

85. Cheow X, Yew A, Ang BFH, Lie DTT. No difference in outcome between articular-sided and bursal-sided tears: comparative study with minimum 2-year follow-up of arthroscopic repairs in 104 patients in a single-surgeon series. Arthroscopy. 2021;37(5):1449-1454. doi:10.1016/j. arthro.2020.12.226

Orthopedic Research and Reviews

Dovepress

\section{Publish your work in this journal}

Orthopedic Research and Reviews is an international, peer-reviewed, open access journal that focusing on the patho-physiology of the musculoskeletal system, trauma, surgery and other corrective interventions to restore mobility and function. Advances in new technologies, materials, techniques and pharmacological agents are particularly welcome. The manuscript management system is completely online and includes a very quick and fair peer-review system, which is all easy to use. Visit http://www.dovepress.com/testimonials.php to read real quotes from published authors.

Submit your manuscript here: https://www.dovepress.com/orthopedic-research-and-reviews-journal 